\title{
REINFORCING THE TRANSFORMATION OF STEREOTYPICAL PERCEPTIONS OF IMPRISONED DRUG USERS ABOUT THE CAUSES OF CRIME: UTILIZING THE METHOD OF "TRANSFORMATIVE LEARNING THROUGH AESTHETIC EXPERIENCE"
}

\author{
Vierou Anna Maria ${ }^{1}$, \\ Natassa Raikou ${ }^{2 i}$ \\ ${ }^{1}$ KETHEA (Therapy Center for \\ Dependent Individuals), \\ Patras, Greece \\ ${ }^{2}$ Department of Educational Sciences \\ \& Early Childhood Education, \\ University of Patras, \\ Patras, Greece
}

\begin{abstract}
:
The commission of criminal acts has always been a social problem, both socially and scientifically engaging. Many theories have been formulated from time to time about what is considered a criminal act, as well as about the factors that contribute to the occurrence of the phenomenon, varying according to the time and the social conditions that prevailed. The study was conducted at the Detention Centre of Patras, with the participation of seven drug users and members of the KETHEA consultation programme. Methodologically, the qualitative approach has been chosen and in particular the action research with the use of group-focused interviews. The research findings are relevant to what one may come across in the bibliography, while at the same time they highlight three basic cause factors of criminal behavior: individual characteristics, family and environmental reasons, with emphasis placed upon the substance abuse, and peer pressure. Moreover, the use of the "Transformative Learning through Aesthetic Experience" method has proven to be extremely functional as far as the alteration of perceptions among groups of users-prisoners is concerned. It can also complement the therapeutic procedure and the social integration of this particular group of people.
\end{abstract}

Keywords: criminality, substance dependence, detention, art, transformative learning through aesthetic experience

i Correspondence: email araikou@patreas.upatras.gr 


\section{Introduction}

Criminal behavior is a learning process that takes place in a specific environment where individual characteristics, family and social influences co-shape people's beliefs, behaviors, and expectations. This kind of behavior is also reinforced by the way people associate it with the acquisition of power and economic prosperity, as well as by the respective social influences.

In criminology, various theories have been developed about the multifactorial nature of the etiology that leads to criminal behavior, which take different directions depending on the subject area of the researcher and the social and historical conditions of the time. According to the biological factors, the causes of crime coming from biological and genetic factors are essentially the first to try to identify the source of criminal behavior (Zafiriou, 2007; Koutouvidis \& Minogianni, 2003).

On the other hand, personality theories aim at the interpretation of criminal or deviant behavior by emphasizing the concept of deviation from the normality of individual characteristics (psychological factors), a fact which in clinical practice, falls into the study of personality disorders (Koutouvidis \& Minogianni, 2003). People with criminal behavior show characteristics such as egocentrism, low self-esteem, lack of ability to take on roles and lack of consciousness (Koutouvidis \& Minogianni, 2003).

There is a theory focusing on social institutions, such as family, school and the wider social environment in which someone grows up, which also play an important role in the process of shaping the personality and behavior of the individual (social factors). Sociological theories perceive crime as a social phenomenon, which has largely cultural, social and economic roots (Araka, 2008; Panousis, 2000).

Finally, another approach seeks to explain crime and delinquent behavior as a result of the interaction of both biological and environmental factors (biosocial factors). People may have a genetic predisposition to delinquent behavior, but they can only commit criminal acts when they encounter the appropriate environmental conditions that favor it (Pappa, 2018).

\section{Transformation theory}

According to Adult Education (AE) approach, in order for people to understand the world around them, they need to create mental maps and avoid the threat of chaos. Given the new conditions that constantly arise in their lives, it is possible that some perceptions they formed mainly in childhood, are not in line with the new reality, causing inconsistencies and difficulties in dealing with them.

Transformative Learning is a rational process of identifying evaluation and redefining dysfunctional beliefs so that we can then be more receptive to impending change (Mezirow, 2007). The experiences we have gained from childhood and the environment in which we grow up determine the way we think as adults. Transformation 
of problematic frames of reference refers to the need to solve these problems so that they are more reliable for adulthood.

Understanding these perceptions is a painstaking process and using art as alternative forms of language can work effectively to address these barriers. The use of art as a form of therapy within specific contexts, is a successful tactic that has been used for many decades as a means of communication (Brock, Dodds, Jarvis, \& Olusoga, 2016). Dirkx characteristically refers to learning through art as "learning through the soul" which includes the "emphasis on the point of interaction, where the social-emotional and the mental world meet" (Mezirow, 2007: 46).

\section{3. "Transformative Learning through Aesthetic Experience" method}

Kokkos (2011) went further to the formulation of the method "Transformative Learning through Aesthetic Experience" (TLAE) with the aim of activating the critical reflection of the learner. It is a structured educational tool and consists of six stages. The applications of the method confirm the efficiency of this approach (Karakou, 2015; Mega, 2011; Raikou, $2016 \& 2019$ ) and highlight the effectiveness of the use of art in groups of prisoners, as well as the use of the TLAE method to review dysfunctional perceptions and the possibility of their transformation (Kotzagiotou, 2015; Mamali, 2018; Bika, 2015; Tsamasfyra, 2015).

International literature has shown that there is a positive correlation between participation in educational activities in prison and the improvement of basic skills (Brosens, De Donder, Vanwing, Dury \& Verte, 2014; Ripley, 1993; Vacca, 2004), that education within imprisonment contributes to self-esteem (Coyle, 2009) and, ultimately, reduces the recurrence of delinquent behavior (Harding, Wyse, Dobson \& Morenoff, 2014; MacKenzie, 2006; Petersilia, 2003). Also, can activate the critical thinking of prisoners, acting as a source of hope and empowerment for personal action (Clements, 2004).

\section{Research objective}

The aim of the research was to investigate the use of the TLAE method as an educational tool, and how it can enhance the transformation of stereotypical perceptions of detained drug users about the causes that led them to crime. The inclusion of the TLAE method as an educational tool in the therapeutic process resulted from the need to explore the possibility of its integration to the therapeutic and educational course of the detainee by supporting him to understand, think critically and transform dysfunctional perceptions in relation to the above causes.

The research questions were:

1) What are the assumptions of detainees about the causes that led them to crime?

2) How can the MMAE method enhance the transformation of these assumptions? 


\section{Methodology}

The method used for conducting the present educational research is qualitative approach. More specifically, action research was chosen as the most appropriate because it is an approach that focuses on social issues and includes processes aimed at improving and empowering people in situations in which they need to take action (Creswell, 2016).

The participants were selected by homogeneous sampling, a purposive sampling technique often used in qualitative research (Creswell, 2016). Their participation was voluntary and the whole process was done with respect to their personal information. The sample that participated in the research was members of KETHEA Counseling groups, detained in Patras prisons. The participants were 7 adult men, aged 32 to 57, with drug use problems, different origins and sentence time. All detainees were chronic drug users and convicted of drug use, serving sentences of 2.5 years or more. Four had also been jailed before, for drug offenses. As for their marital status, 4 were unmarried, 2 married with children and one divorced with a child.

The method that was used for conducting this study was the qualitative approach and the data collection instrument that was used was the focus group interview (Cohen \& Manion, 1994). An analysis of the content of the participants' responses from the questions used was carried out for the processing of the data. (Bryman, 2017). The first step of the process involved recording their views by creating original categories arising from the analysis of the responses during the application of the method. Through this analysis, categories describing their responses were developed. All answers were then assigned to the appropriate resulting categories and the occurrence of each category per participant was counted.

\section{Application of TLAE method}

The educational intervention of the TLAE method application took place in February 2020, in the Detention Centre of Patras, where two 3-hour meetings were held.

\section{- 1st Stage: Investigating the need for critical reflection}

The issue of criminality, either from the perspective of causes or from the perspective of the results, is a common discussion topic among the population of detainees.

\section{- 2nd Stage: The participants express their views}

The members were asked to form small groups and write individual essays on the topic: what are the causes that led me to criminal behavior? They mentioned:

\footnotetext{
"Family environment."

"The milieu. Heroin use since I was 14 and school."

"The groups of friends I got mixed up with and I started selling drugs".

"Young age and wrong groups of friends. Drug use. The financial situation".
} 
"Harsh reality"

\section{- 3rd Stage: Determining the views to be investigated}

Using the answers, they were asked the critical questions, based on which the critical consideration of the artworks was afterwards carried out:

- What is the cause of criminality?

- In what ways could you have handled things differently in order to cope with the aforementioned situations?

\section{- 4th Stage: Selecting the artworks}

The artworks were selected depending on their direct relation to the critical questions under investigation and were used so that the students would reflect on every artwork, without censorship and prejudices. In particular, the painting «The Return of the Prodigal Son» by Rembrandt and the film «Modern Times» by Charlie Chaplin were used.

\section{- 5th Stage: Critical thinking through the aesthetic experience}

The exploration of the visual work was carried out using the technique Visible Thinking by Professor Perkins (1994), through which "the observer adopts a thoughtful view towards the work of art" (Kokkos, 2011:82).

In order to exploit the film, certain excerpts were chosen to be screened, which were relevant to the issue under investigation. First, the title of the film was presented to the students, mentioning basic information about the time it was shot, its style, the plot of the film and the part that the main characters play. Then, the characteristic excerpts were shown with a brief introduction-explanation for the scenes that would follow. A discussion followed during which the participants were asked to rethink on answers or issues that may have reemerged and talk about them again.

After a brief discussion in the groups, they were initially divided into, based on the analysis questionnaire given to them, a plenary discussion was held during which conclusions were drawn and they were associated with the critical questions which had been raised. By way of illustration, they mentioned:

"I identify with him when it comes to struggling and hardship and the same things every day. I just had to struggle for other things".

"I was unlucky too, like the hero. Very unlucky. But he faces everything with a smile and optimism, whereas I don't".

"Since I was a little boy, I've been trying to tell what is illegal, what is right or not. I had many dilemmas". 


\section{- 6th Stage: Reevaluating the assumptions - Focus Group}

The statements and views recorded in the second stage of the intervention were revisited, and the extent, if any, of their exposure to the artworks, which contributed to them diverging from their initial statements, was investigated.

\section{Results}

When the participants were asked about the causes that led them to criminal acts, it was found that the majority share the opinion that it is a complex problem, comprised of many factors. Almost all of them referred to features concerning themselves and their weaknesses as human beings, emphasizing the substance use and its influence on shaping their personality and on their actions. Some of the characteristic personality traits that were mentioned, was the tendency to trust easily, the need to feel accepted by others, as well as the lack of danger and fear.

\section{"Using and dealing" \\ "I brought everything to myself. I was boastful and arrogant" \\ "You have to break the law to get your drugs"}

Family environment is perhaps one of the most important factors that affect the individuals' psychosocial development and help them shape their own personal identity. When parents behave in way where respect and communication are missing, control is inefficient, and the roles within the family have been distorted, it is rather possible that signs of antisocial behavior together with illegal actions will show. The students, when asked about their own opinions on the family factor, focused on the lack of boundaries and control on the part of their parents and the effort to fill the void of their physical or emotional presence through the provision of goods.

\section{"Family problems, many fights" \\ "No relationship with my parents, they only gave me money... they thought they looked after me"}

Finally, all participants referred to the social environment as an etiological factor, including the socio-economic conditions they lived in, such as the area they grew up in, the financial problems, immigration and groups of friends. As the contributing factors to their involvement in criminal actions, they would emphasize the use of drugs and the living conditions in prison, where, according to conducted surveys, $27 \%$ of the suicides committed by inmates were due to drug abuse as a means of reaction toward the inhumane imprisonment and living conditions (Caillard \& Chastung, 2011, as cited in Matsa, 2017).

"I was a family guy and a hard worker, the groups of friends got me into trouble" 
"Hardship, conditions, influence from others"

"Financial situation"

The aforementioned results are consistent with the references under study (Araka, 2008; Koutouvidis \& Minogianni, 2003; Loeber \& Stouthamer-Loeber, 1996; Matsa, 2017; Panousis, 2000), which confirm the three key components of the etiological factors in developing criminal behavior and are related to individual traits (aggressiveness, egocentrism, antisocial behavior, feelings of inadequacy etc.), family (lack of sufficient parental surveillance, harsh discipline, rejection of child etc.) and the environment in which they were raised (high levels of poverty, low social control etc.).

Applying the TLAE method seemed to work and help students to enhance critical thinking on the issue in question, motivating them to consider all the issues concerning them directly in greater depth, such as the realization of the causes that led them to illegal acts. Their stereotypical perceptions of the causes that led them to criminality were given critical consideration, expressing concerns and ambivalence about the way they handled situations and about right and wrong. As they characteristically put it:

"you can live without breaking the law. Our family has done it, so can we"

"the method helped me think about stuff I had never thought about"

"Other people's experiences got me thinking"

\section{Discussion}

The conclusions of this survey, even though not generalizable, may prove useful regarding its findings, for formulating hypotheses and plans of similar educational programmes for vulnerable groups of population, highlighting the importance of integrating the TLAE method, as a new, complementary educational tool which shall play a reinforcing role in the therapeutic process of groups like prisoners and individuals in rehabilitation. The purpose of the method was not for the instructor to change participants' ideas but to give them the opportunity to critically process their personal perceptions and to formulate them in a way that they cover them functionally.

In addition, as shown by researches conducted in prisons (Kotzagiotou, 2015 . Mamali, 2018 - Tsamasfyra, 2015), detainees show a positive attitude when they come in contact with the aesthetic experience.

The use of art and in particular the educational intervention for the application of the TLAE method, gave the imprisoned drug users the opportunity, through active learning and critical thinking, to boost their self-consciousness and come closer to a process of evaluation and transformation of previous dysfunctional assumptions and experiences.

Finally, this survey pointed out the extent to which the therapeutic process is essential for the application of educational tools, which promote critical thinking and reflection, enhancing problem-solving and handling of issues faced by the members of 
therapy groups in their daily lives, thus helping them to make healthy choices for their future. The connection of the therapeutic process through KETHEA programs (empowerment in order to take action and adopt a new attitude to life) with the application of the TLAE method (for the transformation of dysfunctional beliefs), is a dynamic coalition towards rehabilitation and the therapeutic course of people who reach out to us for support. It is important for people who are overwhelmed to be able to share the sources of stress and express their needs, goals and dreams. Works of art, poetry and literature are powerful tools for exploitation so that these people can discuss, understand their fears and anxieties and communicate them to others, recognizing that they have something in common (Comanity, 2020).

\section{Conflict of Interest Statement}

The authors declare no conflicts of interests.

\section{About the Authors}

Anna Maria Vierou, Psychologist, Med, KETHEA (Therapy Center for Dependent Individuals), Patras, Greece.

Dr. Natassa Raikou, Teaching staff in Adult and Higher Education at the University of Patras and Tutor-Counselor at the Hellenic Open University.

\section{Bibliography}

Araka, A. (2008). Juvenile delinquency: young perpetrators or victims. Retrieved from: http://www.alkistis-equal.gr (in Greek)

Bika, Ch. (2015). The contribution of the "Transforming Learning through Aesthetic Experience" method to the Development of Critical Reflection and the Transformation of Established Adult Perceptions: a Metasynthesis of Research (Master thesis). Patras: Hellenic Open University. (in Greek)

Brock, A., Dodds, S., Jarvis, P.\& Olusoga, Y. (2016). Pedagogy of the game in pre-school and school education. Athens: Pedio. (in Greek)

Bryman, A. (2017). Methods of Social Research. Athens: Gutenberg. (in Greek)

Clements, P. (2004). The rehabilitative role of arts education in prison: Accommodation or enlightenment? International Journal of Art E Design Education, 23(2), 169 - 78.

Cohen, L. \& Manion, L. (1994). Methodology of educational research (transl. Ch. Mitsopoulou \& M. Filopoulou). Athens: Metaixmio. (in Greek)

Comanity, (2020). Community Animateur. Retrieved from: https://kt.unir.net/comanity/?lang=el. (in Greek)

Coyle, A. (2009). A human rights approach to prison management: handbook for prison staff. International Centre for Prison Studies. London: International Centre for Prison Studies. 
Creswell, J. (2016). Research in Education - Design Conduct and Evaluation of Quantitative and Quality Research (transl. N. Kouvarakou - Ed. Ch. Tsorbatzoudis). Athens: Ion. (in Greek)

Harding, D., Wyse, J., Dobson, C.\& Morenoff, J. (2014). Making Ends Meet after Prison. Journal of Policy Analysis and Management. 33(2): 440-470.

Karakou, M. (2015). Exploitation of the aesthetic experience in second chance schools in the context of Environmental Literacy. Exploring the possibility of developing critical reflection through 'Transformative Learning through aesthetic experience' method. Master thesis. Patras: Hellenic Open University. (in Greek)

Kokkos, A. (2011). Transformative learning through aesthetic experience: The formation of a method. In Kokkos and Associates. Education through the Arts (71-121). Athens: Metaixmio. (in Greek). (in Greek)

Kotzagiotou, A. (2015). Teaching through art in the education of adult prisoners. The case of the high school in E.A.K.K.N. Kassaveteia. Master thesis. Patras: Hellenic Open University. (in Greek)

Koutouvidis, N. \& Menoyianni, A. (2003). Causal theories of criminal behaviour. Psychiatry, 14(3), 200-209. (in Greek)

Loeber, R. \& Stouthamer- Loeber, M. (1996). The development of offending. Criminal Justice and Behavior, 23(1), 12-24.

MacKenzie, D. L. (2006). What works in corrections: reducing the criminal activities of offenders and delinquents. Cambridge: University Press.

Mamali, P. (2018). The role of culture in the fight against social exclusion in Greece during the economic crisis. Case study: the cultural activities developed in the Penitentiary With the participation of cultural units for the reintegration of prisoners. Master thesis. Patras: Hellenic Open University. (in Greek)

Matsa, K. (2017). Pariahs among the Pariahs. Drug addicts and psychopathology. Athens: Agra. (in Greek)

Mega, G. (2011). Art in the School System as a Stochastic Process. In Kokkos and Associates. Education through the Arts (21-69). Athens: Metaixmio. (in Greek)

Mezirow, J. \& ass. (2007). Transformative Learning. Athens: Metaixmio. (in Greek)

Panousis, G. (2000). Fundamental issues of criminology. Athens: Sakkoula. (in Greek)

Pappa E. (2018). The delinquency and its causes. Transforming stereotypical perceptions of detained drug users by leveraging the Aesthetic Experience. Adult Education, 43, 57-66. (in Greek)

Perkins, D. N. (1994). The Intelligent Eye. Harvard Graduate School of Education.

Petersilia, J. (2003). When prisoners come home: Parole and prisoner reentry. Oxford: University Press.

Raikou, N. (2016). Development of critical thinking through aesthetic experience: the case of students of an educational department. Journal of Transformative Education, 14 (1), 53-70. 
Raikou, N. (2019). Teacher Education at the forefront: Long-term study through the prism of University Pedagogy and Transformative Learning theory. European Journal of Education Studies, 6 (3), 88-102.

Ripley, P. (1993). Prison Education Role in Challenging Offending Behavior. Mendip Papers MP047.

Tsamasfyra, E. (2015). The Use of Works of Art during the educational process in Prison SDEThe case of the SDE of the Women's Prisons of Eleon Thebes. (Master thesis). Patras: Hellenic Open University. (in Greek)

Zafiriou, E. (2007). The social causes of crime. Communist Review, 4. Retrieved on December 2019 from https://www.komep.gr/m-article/0c51d01f-f42b-11e9-95d73ed1504937da/ (in Greek)

Vacca, J. S. (2004). Educated Prisoners are less likely to return to Prison. The Journal of Correctional Education, 55(4), 297-305. 
Creative Commons licensing terms

Authors will retain the copyright of their published articles agreeing that a Creative Commons Attribution 4.0 International License (CC BY 4.0) terms will be applied to their work. Under the terms of this license, no permission is required from the author(s) or publisher for members of the community to copy, distribute, transmit or adapt the article content, providing a proper, prominent and unambiguous attribution to the authors in a manner that makes clear that the materials are being reused under permission of a Creative Commons License. Views, opinions and conclusions expressed in this research article are views, opinions and conclusions of the author(s). Open Access Publishing Group and European Journal of Alternative Education Studies shall not be responsible or answerable for any loss, damage or liability caused in relation to/arising out of conflict of interests, copyright violations and inappropriate or inaccurate use of any kind content related or integrated on the research work. All the published works are meeting the Open Access Publishing requirements and can be freely accessed, shared, modified, distributed and used in educational, commercial and non-commercial purposes under a Creative Commons Attribution 4.0 International License (CC BY 4.0). 